\title{
Relationship Between Body Mass Index and Halitosis Amongst Late Adolescents
}

\author{
Turkan Sezen Erhamza(0000-0001-9540-9906) ${ }^{\alpha}$, Merve Erkmen Almaz (0000-0001-6766-2023) ${ }^{\beta}$,
}

Fatih Tulumbacı(0000-0003-0102-3223) ${ }^{\gamma}$

Selcuk Dent J, 2021; 8: 95-100(Doi: 10.15311/selcukdentj. 730159)

Başvuru Tarihi: 01 Mayıs 2020 Yayına Kabul Tarihi: 16 Kasım 2020

\section{ABSTRACT}

Relationship Between Body Mass Index and Halitosis Amongst Late Adolescents

Background: To the best our knowledge there is no study evaluating relationship between only body mass index (BMI) and halitosis. The aim of our study is to examine whether there is a relationship between $\mathrm{BMI}$ and halitosis.

Methods: For the study population, 200 undergraduate students in the late adolescent period (17-21 years) were evaluated. After the students completed a questionnaire; individuals with good oral hygiene habits (i.e. regular tooth brushing, no caries or filled teeth, no gum bleeding, no systemic diseases, and no drug use) were included in the study. After all the criteria were applied, 61 participants (Male:23, Female:38) were found suitable for the study and BMI of the participants was calculated. Halitosis was determined using organoleptic assessment and a portable sulfur monitor. T-test and simple linear regression model was used for statistical analysis.

Results: The average BMI value was $21.71 \pm 3.09$ for all participants Linear regression analysis showed that participants' organoleptic value increases by 0.008 times for each unit increase of BMI, however, the relationship was found not statistically significant $(p=$ 0.829). A one unit increase of BMI value increases the halimeter measurements value by 0.573 times, but this result was not statistically significant $(p=0.893)$.

Conclusion: We conclude that halitosis is independent of high BMI in itself. However, high BMI may be still a risk factor for halitosis due to problems associated with high BMI and related to halitosis, such as systemic diseases, increased risk of periodontitis, xerostomia, etc.

\section{KEYWORDS}

BMI, Halitosis, Volatile sulfur compounds

Halitosis or oral malodor is the presence of foul-smelling breath, primarily originating from the oral cavity. ${ }^{1}$ Halitosis is a common condition worldwide. Although its prevalence varies depending on various factors (study population, description diagnostic tools, etc.), it is seen in $10-30 \%$ of the general population. ${ }^{2}$ Halitosis is classified as primary halitosis, which originates from the exhalation by the lungs, or secondary halitosis, which relates with the mouth or upper airways. ${ }^{3}$ Secondary halitosis is mostly due to putrefying bacteria living on the dorsum of the tongue and the volatile sulfur compounds (VSCs) produced from food remnants. These VSCs are sulfur

\section{Öz}

Geç Ergenlerde Vücut Kitle Indeksi Ve Halitoz Arasindaki Ilişki

Amaç: Bildiğimiz kadarıyla, sadece vücut kitle indeksi (VKi) ile ağız kokusu arasındaki ilişkiyi değerlendiren bir çalışma yoktur. Çalışmamızın amacı VKi ile ağız kokusu arasında bir ilişki olup olmadığını incelemektir.

Gereç ve Yöntemler: Çalışma popülasyonu için geç ergenlik döneminde (17-21 yaş) 200 lisans öğrencisi değerlendirildi. Öğrenciler bir anket doldurduktan sonra; Ağız hijyeni alışkanlığı iyi olan bireyler (yani düzenli diş fırçalama, çürük veya dolu diş, diş eti kanaması, sistemik hastalık ve ilaç kullanımı yok) çalışmaya dahil edildi. Tüm kriterler uygulandıktan sonra 61 katılımcı (Erkek: 23, Kadın: 38) çalışmaya uygun bulundu ve katılımcıların VKi hesaplandı. Ağız kokusu organoleptik değerlendirme ve portatif bir kükürt monitörü kullanılarak belirlendi. İstatistiksel analiz için $\mathrm{T}$ testi ve basit doğrusal regresyon modeli kullanıldı.

Bulgular: Tüm katılımcılarda ortalama VKi değeri $21.71 \pm 3.09$ idi. Doğrusal regresyon analizine göre, VKI'nin her birim artış। organoleptik değeri 0.008 kat arttığını göstermiş ancak ilişki istatistiksel olarak anlamlı bulunmamıştır $(p=0.829)$. Bununla birlikte VKi değerindeki bir birimlik artış halimeter ölçüm değerini 0.573 kat arttırmasına rağmen bu sonuç istatistiksel olarak anlamlı bulunmamıştır. $(p=0.893)$.

Sonuç: Ağız kokusunun kendi başına yüksek VKI'den bağımsız olduğu sonucuna vardık. Bununla birlikte, yüksek VKi, yüksek VKi ile ilişkili ve sistemik hastalıklar, artan periodontitis riski, kserostomi vb. Gibi sorunlardan dolayı ağız kokusu için hala bir risk faktörü olabilir.

\section{ANAHTAR KELIMELER}

VKi, Ağız kokusu, Uçucu kükürt bileşikleri

compounds, aromatic compounds, nitrogencontaining compounds, amines, short-chain fatty acids, alcohols or phenyl compounds, aliphatic compounds, and ketones. ${ }^{4}$ VSCs with principal components of hydrogen sulfide (H2S), methyl mercaptan $(\mathrm{CH} 3 \mathrm{SH})$ and dimethyl sulfide are the main causes of oral malodor. 5,6

The etiology of halitosis include extrinsic causes, such as alcohol, smoke, onion, etc., and intrinsic causes. ${ }^{7}$ The intrinsic causes can be intra-oral or extra-oral causes. Intra-oral causes are related to

\footnotetext{
${ }^{\alpha}$ Kırıkkale University Faculty of Dentistry, Department of Orthodontics, Kırıkkale, Turkey

${ }^{\beta}$ Kırıkkale University Faculty of Dentistry, Department of Pediatric Dentistry, Kırıkkale, Turkey

${ }^{\gamma}$ Ankara Yildırım Beyazıt University Faculty of Dentistry, Department of Pediatric Dentistry, Ankara, Turkey
} 
infections, lesions, or poor oral hygiene and are responsible for $90 \%$ of the halitosis cases. Extra-oral causes are acute febrile illness, upper respiratory tract infection, pharyngitis/sinusitis, bronchiectasis, cystic fibrosis, diabetes mellitus, leukemia, pyloric stenosis, hepatic failure, renal failure, peptic ulcer [Helicobacter pylori (H.pylori) infection], menstruation, gastroesophageal reflux disease, trimethylaminuria, hypermethioninemia, agranulocytosis etc.. ${ }^{8}$

Halitosis is a health problem that negatively affects social interactions and self-confidence. ${ }^{9}$ and can lead to depression, low self-esteem, or other mood disorders. ${ }^{10,11}$ In previous studies, researchers examined the differences (caries, periodontal index, bleeding index, etc.) between oral health of obese individuals and normal weight individuals. ${ }^{12}$ To the best our knowledge there is no study evaluating relationship between only $\mathrm{BMI}$ and halitosis. Body mass index (BMI) is as a fast and easy method for the analysis of nutritional status. For example, the relationship between poor oral health and obesity can be explained by the quality and frequency of the diet and the low BMI interval, with real functional difficulties that can prevent normal eating. ${ }^{13}$

The aim of our study was to keep the individual variables (tooth brushing habit, cleaning the interface, cleaning the tongue, decayed or filled teeth, no gingival bleeding, no systemic disease, no medication); To examine whether there is a relationship between obesity and bad breath in young adolescents.

\section{MATERIALS AND METHODS}

This study was approved by Kırıkkale University Clinical Research Ethics Committee (04/03). For the study population, 200 undergraduate students in the late adolescent period (17-21 years) attending to Kırıkkale University Faculty of Dentistry were evaluated for the study. Written informed voluntary consent form was taken from students to participate the study.

\section{Selecting participants}

A two-part questionnaire was applied to the participants. In the first part, socio-demographic information, systemic disease and drug use were investigated. In the second part, oral hygiene habits, dietary habits, tobacco/alcohol use and complaints of halitosis were investigated.

After completing the questionnaire, oral examinations of the volunteers were made. Decayed, Missing, and Filled Permanent Teeth (DMFT) scores and periodontal status were recorded. The results of the questionnaire and oral examination were evaluated and individuals with good oral hygiene habits (i.e. regular tooth brushing, cleaning the interface and the tongue, no caries or filled teeth, no gum bleeding, no drug use and systemically healthy individuals were included in the study. After all the criteria were applied, 61 participants (Male:23, Female:38) were found suitable for the study.

The height of the participants was measured in centimeters, using a hard ruler installed vertically and secured with a stable base, and weight was measured in kilograms using a mechanical scale. The BMI was calculated as the ratio of the subject's body weight in $\mathrm{kg}$ to the square of their height in meters.

\section{Halitosis measurement}

Halitosis was determined using organoleptic assessment and a portable sulfur monitor (Halimeters, Interscan corporation, Chatsworth, CA, USA).

Halitosis measurements were done between 8:30 AM and 11:30 AM. Participants were asked to refrain from eating (especially garlic and onion), drinking (e.g. coffee, alcohol), smoking, using minted chewing gum or scented oral hygiene products, and rinsing their mouths at least 2 hours before the measurement. One examiner performed the organoleptic test for all participants. Examiner calibration was done using 0 , $10,50,100,500,1000$ parts per billion (ppb) concentrations of methyl mercaptan. Calibration was complete, with the examiner identifying the the concentration differences. ${ }^{14}$ The participants were asked to sit upright in a dental chair for 3 minutes, close their mouth tightly and then exhale briefly and gently through a paper tube. The examiner stood at a distance of $10 \mathrm{~cm}$ from the participant and scored the exiting air by sniffing. The breath was evaluated with a 6-point scale, where 0: no odor, 1: questionable odor, 2: slight but clearly noticeable odor, 3: moderate odor, 4: strong odor, and 5: extremely foul odor.

For VSC measurement the participants were asked to close their mouth and to breathe through their nose for $3 \mathrm{~min}$ before the Halimeter reading was taken. Following the manufacturer's instructions, the probe of the device was placed in the mouth and the highest value on the digital indicator on Halimeter was recorded. VSC amount in ppb for each individual was recorded as the average of three measurements. According to the manufacturer's scale, VSC values above 110 ppb indicated the presence of halitosis.

\section{Statistical analysis}

The statistical analyses were done using SPSS (version 20.0; IBM, Armonk, NY). The means, standard deviation, median, minimum and maximum values were used in descriptive statistics for 
continuous data.

Percentage values were used for discrete data. Shapiro Wilk test was used to test the normality of data. T-test was used to compare odor measurements in genders. The simple linear regression model was used to analyze the relationship between BMI and halimeter and organoleptic measurements. $p$ value $<0.05$ were considered to present statistical significance.

\section{RESULTS}

A total of 61 individuals participated in the study. The average age of all participants were $19.50 \pm 1.28$ (min17.00- $\max 21.00)$. The average age of males were $19.86 \pm 1.26(\min 17-\max 21)$, and the average age of females were $19.28 \pm 1.21(\min 18-\max 21)$.

The average BMl value was $21.71 \pm 3.09$ for all participants, $23.30 \pm 3.39$ in males (n: 23) and $20.75 \pm$ 2.49 in females ( $n$ : 38). (Table 1) There was a statistically significant difference between the BMI values of males and females $(p=0.003)$.

The average organoleptic value of the participants was $1.29 \pm 0.90$ for all participants, $1.69 \pm 0.92$ in males $(n$ : 23) and $1.05 \pm 0.80$ in females ( $n: 38)$. (Table 2) There was a statistically significant difference between the organoleptic values of males and females. $(p=0.009)$.

Linear regression analysis showed that participants organoleptic value increases by 0.008 times for each unit increase of BMI, however, the relationship was found not statistically important. $(p=0.829)$ (Table 3$)$

The average VSC value for all participants was $118.34 \pm 101.15,157.52 \pm 119.46$ in males $(n: 23)$ and $94.63 \pm 81.08$ in females ( $n: 38)$. (Table 4) There was a statistical difference between VSC values of males and females $(p=0.032)$.

A one unit increase of BMI value increases the halimeter measurements value by 0.573 times, but this result was not statistically significant. (p:0.893) (Table 3)

Table 1.

Descriptive statistics of the BMI, organoleptic score and the VSC values among the participants ( ${ }^{*}$ Student $t$ test)

\begin{tabular}{|c|c|c|c|c|c|c|}
\hline & & Mean & SD & Min & $\operatorname{Max}$ & $P^{*}$ \\
\hline \multirow{3}{*}{ BMI (kg/m2) } & Male & 23.30 & 3.39 & 17.96 & 30.35 & \multirow{2}{*}{0.003} \\
\hline & Female & 20.75 & 2.49 & 16.73 & 25.56 & \\
\hline & Total & 21.71 & 3.09 & 16.73 & 30.35 & \\
\hline \multirow{3}{*}{$\begin{array}{l}\text { Organoleptic } \\
\text { score }\end{array}$} & Male & 1.69 & 0.92 & 1 & 4 & \multirow{2}{*}{0.009} \\
\hline & Female & 1.05 & 0.80 & 0 & 3 & \\
\hline & Total & 1.29 & 0.90 & 0 & 4 & \\
\hline \multirow{3}{*}{ VSC (ppb) } & Male & 157.52 & 119.46 & 25 & 476 & \multirow{2}{*}{0.032} \\
\hline & Female & 94.63 & 81.08 & 8 & 392 & \\
\hline & Total & 118.34 & 101.15 & 8 & 476 & \\
\hline
\end{tabular}

Table 2.

The distribution of BMI among the participants

\begin{tabular}{|c|c|c|c|}
\hline BMI & Male & Female & Total \\
\hline$\left(\mathrm{kg} / \mathrm{m}^{2}\right)$ & $(\mathrm{n}(\%))$ & (n (\%)) & $(\mathrm{n}(\%))$ \\
\hline-20 & $4(17.4)$ & $15(39.5)$ & $19(31.1)$ \\
\hline $20-24.9$ & $13(56.5)$ & $22(57.9)$ & $35(57.4)$ \\
\hline $25-29.9$ & $4(17.4)$ & 1 (2.6) & $5(8.2)$ \\
\hline $30-34.9$ & $2(8.7)$ & 0 & 2 (3.3) \\
\hline
\end{tabular}

Table 3.

The distribution of organoleptic scores among the participants

\begin{tabular}{|cccc|}
\hline Score & $\begin{array}{c}\text { Male } \\
(\mathbf{n}(\%))\end{array}$ & $\begin{array}{c}\text { Female } \\
(\mathbf{n}(\%))\end{array}$ & $\begin{array}{c}\text { Total } \\
(\mathbf{n}(\%))\end{array}$ \\
\hline 0 & 0 & $9(23.7)$ & $9(14.8)$ \\
\hline 1 & $13(56.5)$ & $20(52.6)$ & $33(54.1)$ \\
\hline 2 & $5(21.7)$ & $7(18.4)$ & $12(19.7)$ \\
\hline 3 & $4(17.4)$ & $2(5.3)$ & $6(9.8)$ \\
\hline 4 & $1(4.3)$ & 0 & $1(1.6)$ \\
\hline 5 & 0 & 0 & 0 \\
\hline
\end{tabular}

Table 4.

The distribution of VSC amounts among the participants

\begin{tabular}{|c|c|c|c|}
\hline $\begin{array}{l}\text { vsc } \\
\text { (ppb) }\end{array}$ & $\begin{array}{l}\text { Male } \\
(\mathrm{n}(\%))\end{array}$ & $\begin{array}{l}\text { Female } \\
(\mathrm{n}(\%))\end{array}$ & $\begin{array}{l}\text { Total } \\
\text { (n (\%)) }\end{array}$ \\
\hline$\leq 110$ & $10(43.5)$ & $25(65.8)$ & $35(57.4)$ \\
\hline$>110$ & $13(56.5)$ & $13(34.2)$ & $26(42.6)$ \\
\hline
\end{tabular}

\section{DISCUSSION}

There is a worldwide epidemic of growing obesity epidemic among teenagers as well as adults. ${ }^{15}$ Overweight and obesity are important public health issues associated with increased risk for the development of medical problems such as cardiovascular and cerebrovascular diseases, hypertension, digestive disorders, certain types of cancer, gallbladder disease, dyslipidemia, osteoarthritis and diabetes mellitus. ${ }^{16,17}$ In addition to its systemic effects, it also has many effects on oral health. Obesity has been associated with oral conditions such as periodontal disease, dental caries, dental wear and xerostomia. ${ }^{18}$ Although there have been several studies on the relationship between overweight and oral health, the lack of studies between overweight and halitosis has led us to investigate this issue. All oral conditions were 
kept constant and it was investigated whether there is a relationship between the $\mathrm{BMI}$ and halitosis. The reason for keeping oral conditions constant is to eliminate factors other than the BMI that are known to affect halitosis.

There are several different methods for measuring and assessing halitosis. ${ }^{19,20}$ The three most methods are organoleptic measurement, gas chromatography, and sulfide monitoring. The organoleptic method is performed by the use of the physician's sense of smell by sniffing and evaluating the air from the patient's mouth and nose. Although considered as the gold standard, organoleptic method has several drawbacks such as being a subjective method, risk of crossinfection and exposure of the examiner..$^{21,22}$ Objective measurements of halitosis can be obtained with via monitoring the amount of VSC by gas chromatography or portable halitometers. Gas chromatography and portable sulfur monitors are preferred by many clinicians for their ease of use, and quantitative measurement of the presence of VSCs. ${ }^{21,23}$ However, VSC monitoring can only measure halitosis caused by the VSCs. ${ }^{24}$ By organoleptic method, on the other hand, halitosis caused by non-sulfide components can be detected as well. ${ }^{23}$ In our study, we have used organoleptic method and sulfur monitoring via a portable halitometer. Thus, we aimed to reduce the possibility of errors and increase the reliability of the results by combining the combination of these two methods.

Kim et al. (2015) assessed the prevalence and associated factors of subjective halitosis in Korean adolescents and observed that many factors were related to halitosis: poor health status, overweight or obesity, stress, lower economic levels, fast food consumption, confectionary, the low intake of fruits and vegetables. ${ }^{25}$ The most common causes of halitosis are related to intra-oral problems, such as chronic bacterial infection covering the tongue or associated periodontal diseases, including gingivitis, periodontitis, stomatitis and xerostomia. ${ }^{26}$ Although obesity was regarded as a cause of halitosis in the study by Kim et al. (2015), no information was given about the oral condition of the participants.

Kumar et al. (2009) assessed the relationship of BMI with periodontal health status and observed that subjects had an increased risk of periodontitis by $57 \%$ for each $1-\mathrm{kg} / \mathrm{m} 2$ increase in the BMl. ${ }^{27}$ Al-Zahrani et al. (2003) and Reeves et al. (2006) evaluated the relationship between $\mathrm{BMI}$ and periodontal diseases in adults and observed that the prevalence of periodontitis was higher in obese individuals.28.29 Rosenberg et al. (2007), investigating the relationship between halitosis, BMI and alcohol intake; they stated that alcohol intake and BMI may be factors that help predict halitosis. The study also reports that the $\mathrm{BMI}$ is predictive of halitosis regardless of alcohol consumption. ${ }^{30}$

High BMI has been associated with a variety of ailments, such as diabetes, hypertension, dyslipidemia, cancer, gout, arthritis, fatty liver, and sleep apnea and periodontitis.23,31 Sleep apnea problems related to obesity may cause dry mouth, which presents a risk for halitosis.32 The fact that the study population is in the late stages of adolescence and the number of participants remained in a narrow environment caused restrictions on obtaining more comprehensive data. In our study, all systemic and oral factors that cause halitosis were eliminated and the effect of only BMI on halitosis was evaluated. Although each unit increase in BMI caused an empirical increase in both methods used, the relationship was found statistically not significant.

\section{CONCLUSION}

Considering our findings and previous reports on the relationship between $\mathrm{BMI}$ and halitosis, we conclude that halitosis is independent of high BMI in itself. However, high BMI is still a risk factor for halitosis due to problems associated with high BMI and related to halitosis, such as systemic diseases, increased risk of periodontitis, xerostomia, etc. Longitudinal studies with larger sample size and wider age range are required to confirm the relationship between BMI and halitosis. 


\section{REFERENCES}

1. Seemann R, Conceicao MD, Filippi A, Greenman J, Lenton P, Nachnani $S$, et al. Halitosis management by the general dental practitioner--results of an international consensus workshop. J Breath Res 2014;8:017101.

2. McNab R. Oral malodour-a review. Arch Oral Biol 2008; 53:1-7.

3. Motta LJ, Bachiega JC, Guedes CC, Laranja L,Bussadori SK. Association between halitosis and mouth breathing in children. Clinics 2011; 66:939-942.

4. Campisi G, Musciotto OF, Marco V, Craxi A. Halitosis: could it be more than mere bad breath? Intern Emerg Med 2011; 6:315-319.

5. Lee $\mathrm{CH}$, Kho HS, Chung SC, Lee SW, Kim YK. The relationship between volatile sulfur compounds and major halitosis-inducing factors. J Periodontol 2003; 74:32-37.

6. Calii C, Liberato FL, Pereira AC, Meneghim MC, Goodson JM, Groppo FC. The relationship between volatile sulphur compounds, tongue coating and periodontal disease. Int J Dent Hyg 2009;7:251-255.

7. Yaegaki K, Coil JM. Examination, classification, and treatment of halitosis; clinical perspectives. J Can Dent Assoc 2000;66:257-261.

8. Kapoor U, Sharma G, Juneja M, Nagpal A. Halitosis: Current concepts on etiology, diagnosis and management. Eur J Dent 2016; 10: 292-300.

9. Azodo C, Osazuwa-Peters N, Omili M. Psychological and social impacts of halitosis: a review. J Soc Psychol Sci 2010; 3:74-92.

10.Zalewska A, Zatonski M, Jabłonka-Strom A, Paradowska A,Kawala B, Litwin A. Halitosis--a common medical and social problem. A review on pathology, diagnosis and treatment. Acta Gastroenterolog Belg 2012;75:300-309.

11.Azodo CC, Ogbebor O. Social distance towards halitosis sufferers. Swiss Dent J 2019;129:1026.

12.Frias-Bulhosa J, Barbosa P, Gomes E, Vieira MR, Manso MC. Association between body mass index and caries among 13-year-old population in Castelo de Paiva, Portugal. Rev Portug Esto Medi Dent Cirurg Maxilo 2015;56:3-8.

13. Sheiham A, Steele JG, Marcenes W, Finch S, Walls AWG. The relationship between oral health status and Body Mass Index among older people: a national survey of older people in Great Britain. $\mathrm{Br}$ Dent $\mathrm{J}$ 2002;192:703-706.

14. Shimura M, Yasuno Y, Iwakura M,, Shimada Y, Sakai S, Suzuki K, Sakamoto S. A new monitor with a zinc-oxide thin film semiconductor sensor for the measurement of volatile sulfur compounds in mouth air. J Periodontol 1996; 67:396-402.
15.Willerhausen $B$, Blettner $M$, Kasaj $A$, Hohenfellner K. Association between body mass index and dental health in 1,290 children of elementary schools in a German city. Clin Oral Invest 2007;11:195-200.

16.Saha AK, Sarkar N, Chatterjee T. Health consequences of childhood obesity. Indian $\mathrm{J}$ Pediatr 2011;78:1349-1355.

17.Consultation W, Obesil'y: Preventing And Managing the Global Epidemic. 2000.

18. Modéer T, Blomberg CC, Wondimu B, Julinn A, Marcus C. Association between obesity, flow rate of whole saliva, and dental caries in adolescents. Obesity 2010;18:2367-73.

19. Nakano Y, Yoshimura M, Koga T, Correlation between oral malodor and periodontal bacteria. Microbe\& Infec 2002; 4:679-683.

20.Van den Broek AM, Feenstra L, Baat C, A review of the current literature on aetiology and measurement methods of halitosis. $J$ Dent 2007; 35:627-635.

21.Setia S, Pannu P, Gambhir RS, Galhotra V, Ahluwalia $\mathrm{P}$, Sofat A. Correlation of oral hygiene practices, smoking and oral health conditions with self perceived halitosis amongst undergraduate dental students. J Nat Sci Biol Med 2014; 5(1):67.

22. Vandekerckhove B, Van den Velde S, De Smit M, Dadamio J, Teughels W, Van Tornout M, et al. Clinical reliability of non-organoleptic oral malodour measurements. J Clin Periodontol 2009; 36: 964-969.

23.Armstrong BL, Sensat ML, Stoltenberg JL. Halitosis: a review of current literature. Am Dent Hyg Assoc 2010;84:65-74.

24.Brunner F, Kurmann M, Filippi A. The correlation of organoleptic and instrumental halitosis measurements. Schweiz Monatsschr Zahnmed 2010;120:402-8.

25. Kim SY, Sim S, Kim SG, Park B, Choi HG. Prevalence and Associated Factors of Subjective Halitosis in Korean Adolescents. PLoS One 2015;10:0140214.

26.Porter S, Scully C. Oral malodour (halitosis). $\mathrm{Br}$ Med J. 2006;333:632-5.

27.Kumar S, Dagli RJ, Dhanni C, Duraiswamy P. Relationship of body mass index with periodontal health status of green marble mine laborers in Kesariyaji, India. Braz Oral Res 2009;23:365-369.

28.Al-Zahrani MS, Bissada MS, Borawski EA. Obesity and periodontal disease in young, middle-aged, and older adults. J Periodontol 2003;74:610-615. 
29. Reeves AF, Rees JM, Schiff M, Hujoel P. Total body weight and waist circumference associated with chronic periodontitis among adolescents in the United States. Arch Pediatr Ado Med 2006;160:894-899.

30. Rosenberg M, Knaan T, Cohen D. Association among bad breath, body mass index, and alcohol intake. J Dent Res 2007;86:997-1000.

31. Haslam D, Sattar N, Lean M. Obesity-time to wake up. Br Med J 2006;333:640-642.

32. Rosenberg M. Clinical assessment of bad breath: current concepts. J Am Dent Assoc 1996;127:475-482.

Corresponding Author:

Fatih TULUMBACI

Ankara Yıldırım Beyazıt University

Faculty of Dentistry

Department of Pediatric Dentistry,

Ankara, Turkey

Phone : +90 31232415

E-mail : fatihtulumbacioglu@hotmail.com 